\title{
Internalized Stigma States of Patients with Psychiatric Disease
}

\author{
Süheyla Ergün ${ }^{1}$, Melike Yönder Ertem ${ }^{2}$ \\ (Ministry of National Education, Siirt Anatolian Technic and Business School, Turkey) \\ (Dokuz Eylül University Institute of Health Sciences, Department of Psychiatric Nursing, Turkey)
}

\begin{abstract}
Stigma is the discredit, disparagement, generally dispraise of a person in such a way that will discriminate him against others. Internalization of stigma in society can cause serious damage to the individuals. It is thought that especially analysis of the psychiatry patients' internalized stigma levels and making suitable attempts in the direction of the results will be useful. The sample of this descriptive study consisted of 91 voluntarily participant out patients, who registered and got medication at Community Health Center and Mental Health and Illnesses Hospital in a city in Turkey. Participants were comprised of patients suffering from schizophrenia, feeling disorder, alcohol-drug addiction, and anxiety problems. It was found that total point average of ISMI was 66.0 \pm 15.06 , alienation subscale from subgroups was $13.61 \pm 5.30$, stereotype endorsement subscale was $15.21 \pm 5.10$, perceived discrimination subscale was $11.48 \pm 3.60$; social withdrawal subscale was 13.06 \pm 3.86 ; and stigma resistance subscale was 12.61 \pm 2.88 . As a result, mental health workers should regard internalized stigma as a negative effect on the treatment of mentally ill individuals and should be addressed accordingly in order to increase the life quality of the patients. Repeating the study with a broader sampling number is recommended along with the stratification of patients with respect to psychiatric diagnosis.
\end{abstract}

Keywords: internalized stigma, mental illness, nursing, psychiatry patients, stigma perception.

\section{Introduction}

Stigma is the discredit, disparagement, generally dispraise of a person in such a way that will discriminate him against others. Internalization of stigma in society can cause serious damage to the individuals. ${ }^{1,2}$ Accordingly, stigmatization of the individuals with mental illnesses can cause them to be faced with serious problems in their social relationships as well as it can cause problems in those individuals' adjustments to the therapies. In our country, also the studies carried out about stigmatization show that the individuals with mental illnesses are stigmatized and excluded. ${ }^{3}$ Individuals with mental illnesses primarily selfstigmatize themselves. The course of internalized stigma begins with the diagnosis of one's mental sickness. The pre-existing adverse image pertinent to "mentally sick person "stereotype occupies the thoughts of the psychiatric patient. The perception level of this adverse image is positive correlated with the perception level of internalized stigma gained. In other words, a psychiatric patient, who has a higher tendency to stigmatize other mentally sick individuals, will likely suffer from the same level of internalization of stigma. Internalization of stigma is independent from exposure to objective exclusion or segregation practices. Moreover, a patient's propensity to internalize stigma may not be detected till diagnosis of ones mental sickness. ${ }^{4,5}$ Internalized stigma or self-stigmatization is the act of a psychiatric patient embracing the stigmatizing opinions related to dangerousness and incompetency accepted by the common popular belief. Internalized stigma is conceptualized by the mixture of various self-developed and firmly adopted believes that is disturbing and uncompliant to general public. ${ }^{6}$ Psychiatric patients, same as any other person, interacts with the widespread stereotypes in the environment. These patients, either self or publicly addressed as "mentally ill person", count themselves unwillingly or willingly a member of the group that is the target of the labeling. ${ }^{7,8}$ Even though stigmatization has prevailed in various phenomenon and state, the patients with mental sickness is the one to suffer the most. ${ }^{9}$ The feeling of alienation from the society is the most dramatic and detrimental consequence of stigmatization on the psychiatric patients. ${ }^{7}$ Psychiatric patients stigmatized with "Mentally sick" labeling feel publicly condemned and belittled. This yields to depression, lower self-esteem, social adaptation problems, unemployment, revenue loss, reduction in psychiatric treatment adherence. ${ }^{10}$

Stigmatization perceptions, as much as stigmatization itself, constitute major obstacles for the treatment process and achieving the well-being of the patients. Due to this process, emanating from the patients themselves expressing a subjective stigma, psychiatric patients abstain from receiving or seeking psychiatric help. ${ }^{6}$ Internalized stigma help exacerbate the symptoms of mental sickness, thus harms the patients in the sense of delaying their healing process. ${ }^{11}$ Patients experiencing stigma demonstrate a decline in self-respect since these two variables are interrelated. In addition, dispiritedness, deterioration in social cohesion, and an increase in feelings of guilt and shame can be observed. ${ }^{9}$ Uultimately, stigmatization perceptions stimulate patients to question about their well-deserved place in the society. Ergo, their perceptional fiction for being underrated in the societyhinders the sense of belonging to the community. Attributed to stigmatization perceptions, patients can't return to their social and professional roles in the society, regardless of the effects of the sickness. 
Stigma perceptions lead the patients develop psychological reasoning to isolate themselves from the society and develop behavioral avoidance. Patients that fail in returning to the pre-sickness functionality in the community and establishing previous social bonds are subject to intensified stigma. ${ }^{6}$ Therefore, internalized stigma is an important problem that must be eliminated by emphasizing in therapy process. It is thought that especially analysis of the psychiatry patients' internalized stigma levels and making suitable attempts in the direction of the results will be useful.

\section{Material And Method}

The sample of this descriptive study consisted of 91 voluntarily participant out-patients, who registered and got medication at Community Health Center and Mental Health and Illnesses Hospital in a city in Turkey. Participants were comprised of patients suffering from schizophrenia, feeling disorder, alcohol-drug addiction, and anxiety problems. The participants were 18 years-old and above with no report of any visual, hearing and cognitive impairments that would impede the communication and perception skills. A written permit was obtained from the facility authority to conduct the research. Patients who agreed to participate in the study were informed and their verbal consent were obtained. After a policlinic examination of the patients, face-to-face data collection method were carried out. For data collection, "Individual Description Form" and "Internalized Stigma of Mental Illness Scale (ISMI)", of which developed by Ritsher et al (2003) and carried of the adaptation study by Ersoy and Varan (2007) were used in order to determine the socio-demographic and illness-oriented features of the individuals. ${ }^{7,8}$ For the analysis of data, percentage distribution and Kruskal-Wallis Test were used.

\section{Findings}

Of the psychiatry patients that were taken into the study scope, $63.7 \%$ were male, $48.3 \%$ were single. It was found that, of the patients, $60.4 \%$ did not work for any job, $47.3 \%$ were perceived as they had a medium socio-economic status, $53.8 \%$ lived in cities, $36.3 \%$ were primary school graduates, $40.7 \%$ went to doctor for medical examination whenever they were ill, $89 \%$ took their medicine regularly, 59.3\% took support from their environments for their illnesses, $42.9 \%$ had their family members as their support source. When the illness period of the patients was examined, it was determined that $51.6 \%$ of them have been taking psychiatry diagnosis for $0-5$ years and $12.1 \%$ of them did not know the period of their illnesses.

It was found that total point average of ISMI was $66.0 \pm 15.06$, alienation subscale from subgroups was $13.61 \pm 5.30$, stereotype endorsement subscale was $15.21 \pm 5.10$, perceived discrimination subscale was 11.48 \pm 3.60 ; social withdrawal subscale was 13.06 \pm 3.86 ; and stigma resistance subscale was $12.61 \pm 2.88$. The inter-rater reliability coefficient of ISMI (Cronbach Alfa) was found as 0.81. A statistically meaningful difference was found between the alienation and stereotype endorsement subscale point averages of ISMI according to the psychiatric illness period of which the patients took diagnosis $(p>0.05)$. The approval state of alienation and stereotypes was directly proportional with the duration of diagnosis. No meaningful difference was found between ISMI total and all subscale point averages according to the patients' ages, sexes, education levels, age groups, the diagnosis they took, marital and socio-economic status ( $>0.05)$. According to the patients' working situations, a meaningful difference was found between the point averages of stereotype endorsement which was the subscales of ISMI $(\mathrm{p}<0.05)$ (Table 2).It was found that, according to the places the patients lived; ISMI total and perceived withdrawal subscale point averages of the patients lived in cities meaningfully decreased.

Table 1 ISMI Total and All Subscale Point Averages

\begin{tabular}{|l|l|l|}
\hline $\begin{array}{l}\text { Subscales of Internalized Stigma } \\
\text { of Mental IIIness Scale (ISMI) }\end{array}$ & $\mathbf{N}$ & Mean \pm Sd \\
\hline Alienation & 91 & $13.61 \pm 5.30$ \\
\hline Stereotype Endorsement & 91 & $15.21 \pm 5.10$ \\
\hline Perceived Discrimination & 91 & $11.48 \pm 3.60$ \\
\hline Social Withdrawal & 91 & $13.06 \pm 3.86$ \\
\hline Stigma Resistance & 91 & $12.61 \pm 2.88$ \\
\hline Total & 91 & $66.0 \pm 15.06$ \\
\hline
\end{tabular}

Table 2. The difference between ISMI total and all subscale point averages according to the patients' sociodemographic features

\begin{tabular}{|c|c|c|c|c|c|c|}
\hline Features & $\mathbf{N}$ & $\begin{array}{l}\text { Alienation } \\
\text { Mean Rank }\end{array}$ & $\begin{array}{l}\text { Stereotype } \\
\text { Endorsement } \\
\text { Mean Rank }\end{array}$ & $\begin{array}{l}\text { Perceived } \\
\text { Discriminatio } \\
\text { n Mean Rank }\end{array}$ & $\begin{array}{l}\text { Social } \\
\text { Withdrawal } \\
\text { Mean Rank }\end{array}$ & $\begin{array}{l}\text { Stigma } \\
\text { Resistance } \\
\text { Mean Rank }\end{array}$ \\
\hline \multicolumn{7}{|l|}{ Age Group } \\
\hline 17-24 ages & 11 & 43.45 & 51.23 & 51.32 & 46.09 & 41.77 \\
\hline $25-32$ ages & 26 & 36.37 & 38.15 & 35.50 & 41.00 & 46.58 \\
\hline $33-40$ ages & 18 & 51.06 & 42.44 & 51.31 & 47.89 & 56.08 \\
\hline 41-48 ages & 24 & 49.06 & 49.10 & 48.58 & 51.38 & 41.35 \\
\hline
\end{tabular}


Internalized Stigma States Of Patients With Psychiatric Disease

\begin{tabular}{|c|c|c|c|c|c|c|}
\hline 49-65 ages & 12 & 55.50 & 57.33 & 50.75 & 43.17 & 42.79 \\
\hline & & $\begin{array}{l}\mathrm{KW}=6.141 \\
\mathrm{p}=0.18\end{array}$ & $\begin{array}{l}\mathrm{KW}=5.630 \\
\mathrm{p}=0.22\end{array}$ & $\begin{array}{l}\mathrm{KW}=5.960 \\
\mathrm{p}=0.20\end{array}$ & $\begin{array}{l}\mathrm{KW}=2.174 \\
\mathrm{p}=0.70\end{array}$ & $\begin{array}{l}\mathrm{KW}=3.909 \\
\mathrm{p}=0.41\end{array}$ \\
\hline \multicolumn{7}{|l|}{ Education Level } \\
\hline No formal education & 12 & 56.33 & 57.88 & 53.33 & 56.00 & 44.88 \\
\hline Primary School Graduate & 33 & 51.58 & 47.52 & 47.91 & 48.26 & 48.77 \\
\hline Junior High School Graduate & 10 & 40.75 & 48.15 & 45.40 & 38.00 & 38.05 \\
\hline High School Graduate & 27 & 36.67 & 36.44 & 39.30 & 41.24 & 48.15 \\
\hline \multirow[t]{2}{*}{ University Graduate } & 9 & 45.61 & 50.89 & 50.00 & 47.56 & 39.72 \\
\hline & & $\begin{array}{l}\mathrm{KW}=7.131 \\
\mathrm{p}=0.12\end{array}$ & $\begin{array}{l}\mathrm{KW}=6.487 \\
\mathrm{p}=0.16\end{array}$ & $\begin{array}{l}\mathrm{KW}=3.080 \\
\mathrm{p}=0.54\end{array}$ & $\begin{array}{l}\mathrm{KW}=3.817 \\
\mathrm{p}=0.43\end{array}$ & $\begin{array}{l}\mathrm{KW}=2.015 \\
\mathrm{p}=0.73\end{array}$ \\
\hline \multicolumn{7}{|l|}{ Employment Status } \\
\hline Unemployed & 55 & 44.65 & 42.69 & 44.02 & 43.34 & 48.40 \\
\hline Employed & 18 & 38.36 & 41.03 & 44.50 & 49.78 & 42.28 \\
\hline \multirow[t]{2}{*}{ Retired } & 18 & 57.75 & 61.08 & 53.56 & 50.36 & 42.39 \\
\hline & & $\begin{array}{l}\mathrm{KW}=5.251 \\
\mathrm{p}=0.07\end{array}$ & $\begin{array}{l}\mathrm{KW}=7.422 \\
\mathrm{p}=0.02 *\end{array}$ & $\begin{array}{l}\mathrm{KW}=1.860 \\
\mathrm{p}=0.39\end{array}$ & $\begin{array}{l}\mathrm{KW}=1.430 \\
\mathrm{p}=0.48\end{array}$ & $\begin{array}{l}\mathrm{KW}=1.169 \\
\mathrm{p}=0.55\end{array}$ \\
\hline \multicolumn{7}{|l|}{ Diagnosis Duration } \\
\hline $0-5$ years & 47 & 37.83 & 37.48 & 38.19 & 39.23 & 41.85 \\
\hline $6-10$ years & 11 & 31.41 & 31.00 & 35.77 & 38.45 & 40.82 \\
\hline 11-15 years & 6 & 43.17 & 51.67 & 39.33 & 36.00 & 27.83 \\
\hline \multirow[t]{2}{*}{ 16+years } & 16 & 53.59 & 51.72 & 50.97 & 47.31 & 41.06 \\
\hline & & $\begin{array}{l}\mathrm{KW}=7.521 \\
\mathrm{p}=0.04 *\end{array}$ & $\begin{array}{l}\mathrm{KW}=7.798 \\
\mathrm{p}=0.04 *\end{array}$ & $\begin{array}{l}\mathrm{KW}=4.229 \\
\mathrm{p}=0.23\end{array}$ & $\begin{array}{l}\mathrm{KW}=1.840 \\
\mathrm{p}=0.60\end{array}$ & $\begin{array}{l}\mathrm{KW}=1.991 \\
\mathrm{p}=0.57\end{array}$ \\
\hline
\end{tabular}

Kruskal Wallis Test, ${ }^{*} \mathrm{p}<0.05$

\section{Discussion}

Average of the ISMI total scores from the psychiatric patients in terms of internalized stigma indicated a partial negativity. A study conducted by the Turkish Psychiatric Association Scientific Section for Mood Disorders ascertained the fact that $46 \%$ of patients felt themselves partly or fully incompetent or deficient. $40 \%$ of patients reported feeling themselves partly or fully incompetent or deficient evoked by the surrounding people. ${ }^{12}$ Parallel to those findings, Boyd- Ritsher and Phelan (2004) contemplating psychiatric out patients reported $73.2 \%$ of the respondents scoring higher than the average on the stigma scale. ${ }^{10}$ Another study by Werner et al. (2007) contemplating patients with schizophrenia reported a mid-level presences of internalized stigma. Between 20-33\% of the participants reported high levels of stigmatization. ${ }^{13}$ Similarly, Beyazyüz et al. (2015) reported a high average $(73,68 \pm 8,12)$ for the ISMI scores which suggests an existence of high level stigma. ${ }^{14}$ Considering the results of other studies conducted in our country, the significance of the average ISMI score found in our study could be justified. For instance, a study of 83 patients ${ }^{15}$ with major depressive disorder identified average ISMI score to be $61,93 \pm 16,14$. Moreover, another study sampling 160 patients ${ }^{16}$ with schizophrenia, mood disorder, general anxiety disorder found an average ISMI score of $64,28 \pm 18,98$. In the light of our findings, internalized stigma should be taken into account both in the mild mental illness and chronic states.

Our study yields no significant difference between age, genders, education levels, age groups, type of diagnosis, marital status and socio-economic levels in terms of ISMI total scores and all subscale point average scores. Literature review of the stigma studies show contradictory findings about the effect of socio demo graphic characteristics. According to Baysal's statement, the society focused stigma studies enumerate variables such as status in society (education and socio-economic status), living environment (rural, urban), age and gender to affect social circle attitudes towards the mental problems. ${ }^{17}$ In our study, some socio demo graphic data appear to have similarities with these results. On the contrary, Switaj et al. (2009), found no meaningful relationship between the patient age, gender, education level, marital status, living environment and employment status. ${ }^{18}$ Other studies determined no relationship between the marital status and the internalized stigma. ${ }^{19,20,21,22}$

Beyazyuz et al. (2015) reported existence of no correlation between ISMI scores and the socio demo graphic data, namely, age and education level. ${ }^{14}$ Additionally, Üstündağ and Kesebir (2013) determined no significant difference between gender and ISMI scores in a study with 100 bipolar disorder diagnosed patients. ${ }^{16}$ On the other hand, a study conducted by Watson et al. (2001) enumerated a couple of variables namely disease level, socio-economic situation and the use of services to effect the internalized stigma. ${ }^{23}$ Zarringer (2002) reported social statue and education level to be positive correlated and age to be negative correlated with augmenting internalized stigma levels. ${ }^{24}$ Our study concurred with the findings of Zarringer (2002)as the retired patients had high stereotype endorsement mean ranks. Our study showed a meaningful difference between "living environment" variable and the ISMI total scores. Our study findings concur with the majority of internalized stigma studies carried out both abroad and domestically with regards to the issue that patients from rural area were more subject to internalized stigma than the ones from cities. ${ }^{4,25,26}$ Relevant literature highlighted an elevated level of attitude towards stigma, stereotypes and prejudice in rural 
areas. For instance, a study by Angermayer et al. (2004) showed that stigma perceptions of the patients from the rural areas were higher in comparison with the patients from the cities. ${ }^{25}$ In our country, a study conducted in depressed patients concurred with the findings of Angermayer et al. (2004).The higher presence of internalized stigma in the rural areas may not always be justified by stigma related attitudes, stereotypes and prejudice since one may speculate that the time frame for noticing patient's disease in rural areas is expected to be shorter given the fact that the village life dwells on a more interwoven, close social interactions with a rich social theme and larger family framework. ${ }^{25}$ Naturally, even if the stigma related attitudes, stereotypes and prejudice are assumed to be same in rural area versus city, the stigma perception levels for the rural area is expected to be higher. Comparison of rural areas to city centers in the context of stigma and stigmatization results should be also scrutinized since the social support system construct in rural areas is better compared to division of labor in the city centers in which patients are more like to be exposed to discrimination. Considering the wider tolerance framework of village life and despite the elevated levels of stigma pressure felt in the rural areas, a study about how discrimination differs between rural areas and city centers needs to be done. In this study, there is meaningful difference between the ISMI Alienation and ISMI stereotype endorsement subscale point averages according to the patients' diagnosed psychiatric disease durations. A study by Watson et al.(2001) emphasize the effect of psychiatric disease duration variable on internalized stigma. Increase in disease durations caused an increase in internalized stigma level. ${ }^{23}$ As the disease got chronical, the patients were more subject to stigmatization and tended to internalize accordingly.

\section{Conclusion}

Fighting against stigma requires training individuals with mental illness to have them develop necessary skills in rejecting internalized stigma, resisting public labeling while keeping the bounds with the society in a constructive manner. Individuals with internalized stigma can be relayed information about the mental illness which can help them challenge the negative beliefs about their disease. This requires proactive involvement of mental health professionals' in particular academic nurses or the experienced field nurses in the set up of stigma mitigation organizations. Nurses may participate in letter writing campaigns in order to control patient induced misconceptions and false depictions about their states by means of protesting and taking corrective actions to promote the treatment of mental disorder. Nurses should also attend informative sessions at institutes and businesses to share the problem and create an awareness in order to take the initiative a step further. As a result, mental health workers should regard internalized stigma as a negative effect on the treatment of mentally ill individuals and should be addressed accordingly in order to increase the life quality of the patients. Repeating the study with a broader sampling number is recommended along with the stratification of patients with respect to psychiatric diagnosis.

\section{References}

[1]. A. Üçok, Şizofreni: Damga, mitler ve gerçekler, Psikiyatri Dünyası, (3), 1999, 67-71.

[2]. A. Bahar, Şizofreni ve damgalama, Fırat ağlık Hizmetleri Dergisi, 2(4), 2007.

[3]. E. Özmen, EO. Taşkın, D. Özmen, MM. Demet, Hangi etiket daha damgalayıcı: ruhsal hastalık mı? akıl hastalığı mı?,Türk Psikiyatri Dergisi; 15(1), 2004, 47-55.

[4]. EO. Taşkın, İçselleştirilmiş damgalama ve damgalama algısı, içinde EO. Taşkın (Ed), Stigma ruhsal hastalıklara yönelik tutumlar ve damgalama, (İzmir: Meta Basım ve Matbaacılık; 2007) 31-40.

[5]. O. Çam, D. Çuhadar, Ruhsal hastalığa sahip bireylerde damgalama süreci ve içselleştirilmiş damgalama, Psikiyatri Hemşireliği Dergisi,2(3), 2011, 136-140.

[6]. PT. Yanos, D. Roe, PH. Lysaker, Narrativeenhancement and cognitivetherapy: a new group based treatment forinternalizedstigmaamongpersonswith severe mentalillness. Journal of International GroupPsychotherapy, (61), 2011, 576-95.

[7]. J. Boyd-Ritsher, PG. Otilingam, M. Grajales, Internalizedstigma of mentalillness: psychometricproperties of a newmeasure, PsychiatricResearch, 121, 2003, 31-49.

[8]. M. Ersoy, A. Varan, Ruhsal hastalıklarda içselleştirilmiş damgalama ölçeği Türkçe formunun güvenilirlik ve geçerlilik çalışması, Türk Psikiyatri Dergisi, (18), 2007, 163-71.

[9]. EO. Taşkın, Ruhsal Hastalıklarda damgalama ve ayrımcılık,içinde EO. Taşkın (Ed). Stigma ruhsal hastalıklara yönelik tutumlar ve damgalama, (İzmir: Meta Basım ve Matbaacılık; 2007) 17-30.

[10]. J. Boyd-Ritsher, JC. Phelan, Internalizedstigmapredictserosion of morale amongpsychiatricoutpatients, PsychiatryResearch(129), 2004, 257-65.

[11]. D. Peterson, A. Barnes, C. Duncan, Fightingwithshadows: self-stigmaandmentall illness.1st ed. (Auckland: MentalHealth Foundation of New Zealand, 2008).

[12]. Aydemir Ö. Bipolar bozukluğa yönelik tutumlar ve damgalama,içindeEO. Taşkın, (Ed). Stigma ruhsal hastalıklara yönelik tutumlar ve damgalama. (İzmir: Meta Basım ve Matbaacılık, 2007). 156-65.

[13]. P. Werner, A. Aviv, Y. Barak, Self-stigma, self esteemandage in personswithschzophrenia, International Psychogeriatrics, 2007,115 .

[14]. M. Beyazyüz, E. Beyazyüz, Y. Albayrak, S. Baykal, E. Göka, Bir eğitim araştırma hastanesi psikiyatri polikliniğine başvuran hastalarda içselleştirilmiş damgalanma düzeylerinin bazı tanı grupları, sosyo-demografik özellikler ve benlik saygısı ile ilişkisi, Türk Psikiyatri Dizini, 53(2), 2015, 2-13.

[15]. P. Çelik, Celal Bayar Üniversitesi hastanesi psikiyatri polikliniğine başvuran depresif bozukluklu hastalarda içselleştirilmiş damgalanma ve ilişkili değişkenler,Doctoraldiss., Celal Bayar Universitesi Sağlık Bilimleri Enstitüsü, 2012. 
[16]. MF. Üstündağ, S. Kesebir, İki uçlu bozuklukta içselleştirilmiş damgalanma: Klinik özellikler, yaşam kalitesi ve tedaviye uyum ile ilişkisi. Türk Psikiyatri Dergisi,24(4), 2013, 231-39.

[17]. GÖD. Baysal, Damgalanma ve Ruh Sağlığı, Arşiv Kaynak Tarama Dergisi, 22(2), 2013, 239-251.

[18]. P. Switaj, J. Wciórka, J. molarska-Switaj, P. Grygiel, Extentandpredictors of stigmaexperiencedbypatientswithschizophrenia. EurPsychiatry, 24, 2009, 513-20.

[19]. B. Arkan, K. Bademli, ZÇ. Duman, Sağlık çalışanlarının ruhsal hastalıklara yönelik tutumları: son 10 yılda Türkiye'de yapılan çalışmalar, Psikiyatride Güncel Yaklaşımlar-CurrentApproaches in Psychiatry, 3, 2011, 214-31.

[20]. E.K. Saillard, Psychiatristviews on stigmatizationtowardpeoplewithmentalillnessandrecommendations. Türk Psikiyatri Dergisi, 21, 2010, 14-24.

[21]. N. Bostancı, Ruhsal bozukluğu olan bireylere yönelik stigma ve bunun azaltılmasına yönelik uygulamalar. Düşünen Adam, 18, 2005, 32-8.

[22]. O. Taşkın, EY. Gürlek, A. Deveci, E. Özmen, Psikiyatri polikliniğine başvuran hastaların depresyona yönelik tutumları. Anadolu Psikiyatri Dergisi, 10, 2009, 100-8.

[23]. AC. Watson, PW. Corrigan.Theimpact of stigma on service accessandparticipation. 1st ed. (ChicagoBehavioralHealthRecovery Management), 2001. p. 13-7.

[24]. A. Zarringer, Psychiatryandstigmatization, Journal of theAmericanMedicalAssociationPsychiatry, $287,2002,1856$.

[25]. MC. Angermeyer, M. Beck, S. Dietrich, A. Holzinger. Thestigma of mentalillness: patientsanticipationsandexperiences, International JournalSocialPsychiatry, 50(2), 2004, 153-62.

[26]. BG. Link, Understandinglabellingeffects in thearea of mentaldisorders: an assessment of theeffects of expectations of rejection. AmSociolRev, 52(1), 1987, 96-112. 